\title{
A Molecular Signature of Two Long Non- Coding RNAs in Peripheral Blood Predicts Acute Renal Allograft Rejection
}

\author{
Yu-Zheng Ge $e^{a, b}$ Tao Xuc Wei-Jun Cao ${ }^{d}$ Ran Wu ${ }^{a, b}$ Wen-Tao Yao a,b \\ Chang-Cheng Zhou ${ }^{a, b}$ Min Wang ${ }^{a, b}$ Lu-Wei Xu ${ }^{a, b}$ Tian-Ze Lu ${ }^{e}$ You-Cai Zhao ${ }^{f}$ \\ Zhi-Kai Hu ${ }^{\mathrm{a}, \mathrm{b}}$ Zhong-Le Xu ${ }^{\mathrm{b}}$ Xiao-Bing Yang ${ }^{f}$ Liu-Hua Zhou ${ }^{\mathrm{a}, \mathrm{b}}$

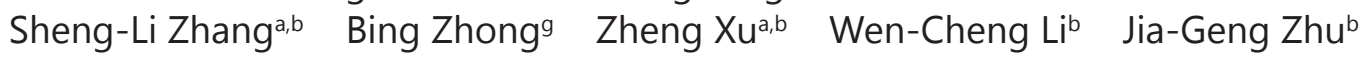 \\ Rui-Peng Jia ${ }^{a, b}$ \\ ${ }^{a}$ Center for Renal Transplantation, Nanjing First Hospital, Nanjing Medical University, Nanjing, \\ 'Department of Urology, Nanjing First Hospital, Nanjing Medical University, Nanjing, 'General \\ Clinical Research Center, Nanjing First Hospital, Nanjing Medical University, Nanjing, dDepartment of \\ Gastroenterology, Nanjing First Hospital, Nanjing Medical University, Nanjing, eDepartment of Urology, \\ Nantong Hospital of Traditional Chinese Medicine, Nantong, fDepartment of Pathology, Nanjing First \\ Hospital, Nanjing Medical University, Nanjing, 9Department of Urology, The First Hospital of Nanchang, \\ Nanchang University, Nanchang, China
}

\section{Key Words}

Renal transplant • Acute rejection • Long non-coding RNA • Diagnosis • Biomarker

\begin{abstract}
Background/Aims: Acute rejection (AR) is a major complication post renal transplantation, with no widely-accepted non-invasive biomarker. This study aimed to explore the expression profiles of long non-coding RNAs (IncRNAs) in the peripheral blood (PB) of renal transplant recipients and their potential diagnostic values. Methods: The genome-wide IncRNA expression profiles were analyzed in 150 PB samples from pediatric and adult renal transplant (PRTx and ARTx) cohorts. The diagnostic performance of differentially expressed IncRNA was determined using receiver operator characteristic curve, with area under the curve (AUC) and 95\% confidential interval (CI). Finally, a risk score was constructed with logistical regression model. Results: A total of 162 IncRNAs were found differentially expressed in PRTx cohort, while 163 in ARTx cohort. Among these identified IncRNAs, 23 deregulated accordingly in both cohorts, and could distinguish AR recipients from those without AR. Finally, a risk score with two most significant IncRNAs (AF264622 and AB209021) was generated and exhibited excellent diagnostic performance in both PRTx (AUC:0.829, 95\% CI:0.735-0.922) and ARTx cohorts (AUC: $0.889,95 \%$ CI: 0.817-0.960). Conclusion: A molecular signature of two IncRNAs in PB could serve as a novel non-invasive biomarker for the diagnosis of AR in both pediatric and adult renal transplant recipients.

Y. Ge, T. Xu, and W. Cao contributed equally to this work. 


\section{Cellular Physiology Cell Physiol Biochem 2017;44:1213-1223 and Biochemistry Published \begin{tabular}{l|l} 
DOI: 10.1159/000485451 & $\begin{array}{l}\text { C } 2017 \text { The Author(s). Published by S. Karger AG, Basel } \\
\text { www.karger.com/cpb }\end{array}$
\end{tabular}}

Ge et al.: Long Non-Coding RNA and Acute Renal Allograft Rejection

\section{Introduction}

Renal transplantation is the preferred treatment of choice for patients with end stage renal disease (ESRD) [1, 2]. Despite substantial improvements in immunosuppressive therapies and surgical techniques, acute rejection (AR) remains a frequent and serious posttransplantation complication, which contributes to late allograft loss and mortality $[3,4]$. To date, the gold standard for diagnosing AR relies on multiple and repeated renal allograft biopsies. Although this invasive procedure has become safer over the years, challenges and complications still exist such as sampling error, inter-observer variability, bleeding, arteriovenous fistula, graft loss, and even death [5]. Hence, development of noninvasive and reliable biomarkers of AR is one of the major objectives in renal transplantation, and various efforts have been made to identify such biomarkers in the peripheral blood (PB) and urine of renal transplant recipients [6-9].

The rapid advances in the depth and quality of transcriptome sequencing have led to the discovery of thousands of long non-coding RNAs (lncRNAs) [10]. As newly discovered members of RNA, lncRNAs are generally defined as transcripts longer than 200 nucleotides with little or no protein-coding potential [11]. A growing body of evidence indicates that IncRNAs could regulate gene expression at the transcriptional and/or post-transcriptional levels, and play fundamental roles in a diverse array of biological processes such as cell cycle control, development, carcinogenesis, and immune response [12-15]. A large number of dysregulated lncRNAs have been identified in the renal cortex tissues of AR recipients [1618]. Recently, Lorenzen and colleagues have analyzed the lncRNA expression profiles in the urine of renal transplant recipients, and demonstrated that urinary RP11-354P17.15-001 could serve as a novel biomarker of acute T cell-mediated rejection (ATMR) of renal allografts [19]. However, to date, the lncRNA expression patterns in the PB of renal allograft recipients have not yet been investigated.

In the current study, we comprehensively analyzed the IncRNA expression profiles in the PB samples of patients from two cohorts: adult renal transplant (ARTx) and pediatric renal transplant (PRTx) cohorts [6, 7], with the aim to: 1) explore the differentially expressed lncRNAs in PB of renal transplant recipients with and without AR; 2) identify the circulating IncRNAs that could distinguish recipients with AR from those without; 3) generate a lncRNA signature in PB which could serve as a novel diagnostic biomarker of AR in both adult and pediatric renal transplant recipients.

\section{Materials and Methods}

\section{Study population}

This two-cohort observational study was conducted and reported in accordance with the STROBE (Strengthening the Reporting of Observational studies in Epidemiology) guidelines [20]. In the PRTx cohort, all patients received the renal transplantation at Stanford University and routinely followed up for two years [6]. In the ARTx cohort, the subjects were randomly recruited from five different clinical centers including Scripps Clinic, Cleveland Clinic, St. Vincent Medical Center, University of Colorado, and Mayo Clinic Arizona [7]. The renal biopsies were scored by at least two pathologists blindly and independently according to Banff classification [21]. Finally, a total of 150 biopsy-defined AR and stable (STA) recipients with corresponding PB samples were included (PRTx: $=75$, ARTx: $n=75$ ), and the detailed selection criteria have been described previously [6,7]. All subjects were well informed and provided written consent, and the appropriate approvals were obtained from the corresponding institutional review boards $[6,7]$. Furthermore, the protocol of current study was approved by the institutional review board of Nanjing First Hospital, Nanjing Medical University.

RNA isolation and IncRNA expression profiling

Each PB sample was paired with renal allograft biopsy (in PRTx cohort: within 48 hours; in ARTx cohort: at the time of biopsy), and collected in $2.5 \mathrm{ml}$ PAXgene Blood RNA Tubes (PreAnalytiX, Qiagen, 


\section{Cellular Physiology Cell Physiol Biochem 2017;44:1213-1223 \begin{tabular}{l|l|l} 
DOI: 10.1159/000485451 & $\begin{array}{l}\text { O 2017 The Author(s). Published by S. Karger AG, Basel } \\
\text { www.karger.com/cpb }\end{array}$
\end{tabular} \\ Ge et al.: Long Non-Coding RNA and Acute Renal Allograft Rejection}

Valencia, CA; or PreAnalytiX GmbH, Hombrechtikon, Switzerland), and total RNA was extracted using the PAXgene Blood RNA Kit according to the manufacturer's instructions [6, 7]. The well-prepared cDNA was hybridized to Affymetrix Human Genome U133 (HG-U133) Plus 2.0 GeneChips (Affymetrix Inc., Santa Clara, CA), and the raw expression data were deposited in Gene Expression Omnibus database (accession numbers: GSE14346 for PRTx cohort and GSE15296 for ARTx cohort). Even though Affymetrix HG-U133 Plus 2.0 array was initially designed to profile protein-coding mRNAs, it fortuitously contains a large group of IncRNA-specific probes, which makes it possible to explore the IncRNA expression patterns via mining and repurposing the previously published expression microarray data [14, 15]. After quantile normalized and background adjusted with Robust Multichip Average, the microarray data was processed in the $\mathrm{R}$ software (version 2.11.1; R Foundation for Statistical Computing, Vienna, Austria) with GATExplorer (file name: ncrnamapperhgu133plus2cdf_3.0) to determine the re-annotated lncRNA expression levels [22]. According to the predesigned selection criteria: 1 ) with at least three probes mapped uniquely to the RNAdb database [23]; 2) validated in NONCODE: an interactive database with the most complete collection and annotation of IncRNAs [24]; 3) raw expression level more than 1 in at least $10 \%$ of all samples; 4) with changes of more than 1.5 -fold from the median value in at least $20 \%$ of samples, the eligible lncRNAs were retained for further analysis.

\section{Statistical Analysis}

The continuous variables were compared using Student's $t$ test after the normality status confirmed with Kolmogorov-Smirnov and Shapiro-Wilk tests. The differentially expressed lncRNAs in PB between two groups (AR vs. STA) were determined with Significance Analysis of Microarrays (SAM) method embedded in BRB-Array tools (version 4.5.1; National Cancer Institute, Bethesda, MD, USA), which were developed by Dr. Richard Simon and BRB-Array Tools Development Team [25]. To minimize false positives, SAM analysis was performed using stringent statistics variables with a false discovery rate (FDR) less than 0.05 , and permutation of 1000. The differentially expressed IncRNAs were defined as those greater than 1.5 in fold change between groups. In addition, the unsupervised hierarchical cluster analysis was performed with one minus correlation and average linkage methods. Receiver operating characteristics (ROC) curves were constructed to assess sensitivity, specificity, and respective area under the curve (AUC) with 95\% confidential interval (CI). After cross matched in two cohorts, two most significant lncRNAs (one upregulated and one downregulated) in terms of AUC were selected to generate the Acute Rejection Risk Score (ARRS) with logistical regression model [26]. The value with the highest accuracy (i.e., minimal false-negative and false positive rates) was chosen as the optimal cutoff value. Statistical significance was taken as a two-tailed $P$ value $<0.05$ unless specifically indicated. The statistical analyses were performed using BRB-Array Tools and SPSS (version 21.0; SPSS Institute Inc., Chicago, IL, USA), as appropriate.

\section{Results}

\section{Patient characteristics}

In this two-cohort observational study, a total of 150 renal transplant recipients were included, with paired PB and renal biopsy samples. In the PRTx cohort $(\mathrm{n}=75)$, a summary of 38 recipients experienced AR episodes during the two-year follow up. In the ARTx cohort $(n=75)$, fifty one patients suffered from biopsy-proven AR episodes. No significant difference was observed in the distribution of age, gender, and human leukocyte antigen (HLA) mismatch between AR and STA recipients in both cohorts, and the detailed information has been described previously [6, 7].

\section{Differentially expressed IncRNAs in PB of renal transplant recipients}

After mining Affymetrix HG-U133 Plus 2.0 array with GATExplorer, a total of 5635 lncRNA transcripts were identified with at least three probes mapped uniquely to them, which were further confirmed in NONCODE. In PRTx cohort, a total of 162 lncRNAs were found differentially expressed between two groups (Table 1), among which six lncRNAs were upregulated in AR recipients' PB. Similarly, a summary of 163 lncRNAs were demonstrated to express differentially between two groups in ARTx cohort (Table 2). However, unlike the PRTx cohort, most lncRNAs $(113 / 163,69.3 \%)$ were upregulated. In addition, the unsuper- 


\begin{tabular}{|c|c|}
\hline Cellular Physiology & Cell Physiol Biochem 2017;44:1213-1223 \\
\hline and Biochemistry & 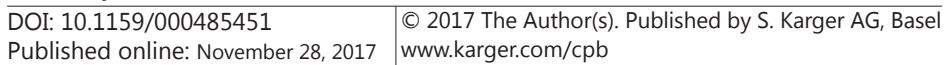 \\
\hline
\end{tabular}

Table 1. Summary of differentially expressed IncRNAs in peripheral blood of pediatric renal transplant recipients

\begin{tabular}{|c|c|c|c|c|c|c|c|}
\hline IncRNA & $\mathrm{FC}$ & IncRNA & $\overline{F C}$ & IncRNA & FC & IncRNA & $\mathrm{FC}$ \\
\hline AF264622 & 2.54 & AL117474 & 0.64 & AK022133 & 0.6 & AF126109 & 0.54 \\
\hline AK024956 & 1.88 & AL713660 & 0.64 & AK023395 & 0.6 & ВС040884 & 0.54 \\
\hline AK026079 & 1.81 & CR613326 & 0.64 & AK021610 & 0.6 & AK000115 & 0.53 \\
\hline AK055877 & 1.77 & AK093869 & 0.64 & CR625974 & 0.6 & AL050376 & 0.53 \\
\hline ВС026299 & 1.69 & AK025015 & 0.64 & AK021623 & 0.59 & ВС016795 & 0.52 \\
\hline AK024375 & 1.64 & АК022339 & 0.64 & АК027193 & 0.59 & AK027156 & 0.52 \\
\hline CR620977 & 0.66 & AK095317 & 0.64 & AK094817 & 0.59 & AK098425 & 0.52 \\
\hline CR597405 & 0.66 & AF339810 & 0.63 & uc003tgp.1 & 0.59 & АК021632 & 0.52 \\
\hline AK056140 & 0.66 & AK090686 & 0.63 & AF052160 & 0.59 & ВС032347 & 0.51 \\
\hline АК025785 & 0.66 & АК096804 & 0.63 & AF211977 & 0.59 & ВС040965 & 0.51 \\
\hline CR625009 & 0.66 & ВС090942 & 0.63 & АК095817 & 0.59 & АК026295 & 0.51 \\
\hline АК091100 & 0.66 & АK095023 & 0.63 & АК093327 & 0.59 & AF306939 & 0.51 \\
\hline ВС041001 & 0.66 & CR611332 & 0.63 & AF086063 & 0.59 & ВС029907 & 0.51 \\
\hline АК022078 & 0.66 & CR608275 & 0.63 & AK124227 & 0.59 & BC142985 & 0.51 \\
\hline AJ420595 & 0.66 & AK055719 & 0.63 & AK024981 & 0.58 & АК057167 & 0.5 \\
\hline CR594753 & 0.66 & CR606559 & 0.62 & AK074610 & 0.58 & AK123904 & 0.5 \\
\hline U63542 & 0.66 & ВС036622 & 0.62 & CR617316 & 0.58 & uc001yfy.1 & 0.5 \\
\hline АК021636 & 0.66 & AF086270 & 0.62 & BC037916 & 0.57 & AK125443 & 0.5 \\
\hline AF085998 & 0.66 & ВС041937 & 0.62 & AK094078 & 0.57 & ВС067863 & 0.49 \\
\hline АК093907 & 0.66 & AK094724 & 0.62 & AK123567 & 0.57 & CR618720 & 0.49 \\
\hline АК025546 & 0.66 & АК074440 & 0.62 & AF070592 & 0.57 & AL050082 & 0.49 \\
\hline АК026716 & 0.65 & AK056007 & 0.62 & AX775927 & 0.57 & ВС005232 & 0.48 \\
\hline ВС039426 & 0.65 & X61080 & 0.62 & АК022181 & 0.57 & AL049423 & 0.48 \\
\hline АК025317 & 0.65 & AK054895 & 0.62 & CR617865 & 0.57 & AK001279 & 0.48 \\
\hline ВС034813 & 0.65 & AK311180 & 0.62 & AK090972 & 0.57 & AK024870 & 0.46 \\
\hline АК026895 & 0.65 & АК024118 & 0.62 & CR617898 & 0.57 & АК025613 & 0.46 \\
\hline ВС035091 & 0.65 & AL833464 & 0.62 & ВС040834 & 0.56 & ВС032890 & 0.44 \\
\hline ВС016013 & 0.65 & AK128410 & 0.62 & АК026078 & 0.56 & AF363068 & 0.44 \\
\hline AL833181 & 0.65 & АК097526 & 0.62 & ВС067908 & 0.56 & AB209021 & 0.43 \\
\hline BC001739 & 0.65 & АК096487 & 0.62 & BC040991 & 0.56 & АК096729 & 0.43 \\
\hline ВС035168 & 0.65 & АК098081 & 0.62 & АК098497 & 0.56 & АК095793 & 0.43 \\
\hline AK056630 & 0.65 & AK124183 & 0.62 & U79271 & 0.56 & AL157495 & 0.42 \\
\hline AF400487 & 0.65 & AF086097 & 0.62 & AK123548 & 0.56 & BC043240 & 0.41 \\
\hline АК022479 & 0.64 & AF075087 & 0.62 & BX537508 & 0.56 & AK055670 & 0.4 \\
\hline uc002ldy.1 & 0.64 & АК023469 & 0.62 & BC054012 & 0.56 & АК024934 & 0.4 \\
\hline AF086031 & 0.64 & AK123379 & 0.61 & CR749703 & 0.55 & АК001086 & 0.4 \\
\hline DQ786290 & 0.64 & AF379627 & 0.61 & AK025702 & 0.55 & AL049951 & 0.39 \\
\hline AK056744 & 0.64 & АК095250 & 0.61 & ВС038181 & 0.55 & AL832284 & 0.38 \\
\hline AL833737 & 0.64 & AK128638 & 0.61 & BC033248 & 0.54 & AY007155 & 0.36 \\
\hline АК026900 & 0.64 & CR622106 & 0.61 & АК098491 & 0.54 & & \\
\hline ВС067233 & 0.64 & BC041913 & 0.61 & BX648207 & 0.54 & & \\
\hline
\end{tabular}

vised hierarchical clustering with lncRNA expression data could clearly distinguish AR from STA recipients in both cohorts (Fig. 1). Finally, a total of 23 lncRNAs were found dysregulated accordingly in both cohorts (Fig. 2), among which two were upregulated and the remaining 21 were downregulated.

\section{Identification of IncRNAs capable of distinguishing AR from STA renal recipients}

To assess the diagnostic capabilities of all the 23 IncRNAs, ROC curves were constructed, and the AUC with corresponding 95\% CI was generated for each lncRNA in two cohorts (Table 3). The results confirmed that all these lncRNAs could discriminate AR from STA patients with moderate to excellent diagnostic performance. As presented in Table 1 and Fig. 
Table 2. Summary of differentially expressed IncRNAs in peripheral blood of adult renal transplant recipients

\begin{tabular}{|c|c|c|c|c|c|c|c|}
\hline $\begin{array}{l}\text { IncRNA } \\
\end{array}$ & $\mathrm{FC}$ & IncRNA & $\mathrm{FC}$ & IncRNA & $\mathrm{FC}$ & IncRNA & $\mathrm{FC}$ \\
\hline AK021643 & 2.74 & BC012054 & 1.65 & AK091776 & 1.55 & AK091335 & 0.63 \\
\hline AF264622 & 2.55 & ВС028913 & 1.65 & ВC017275 & 1.54 & AK123531 & 0.63 \\
\hline АК022204 & 2.29 & AK025048 & 1.64 & АК091544 & 1.54 & АК096729 & 0.63 \\
\hline AF085924 & 2.16 & АК094623 & 1.64 & АК022801 & 1.54 & BC045174 & 0.63 \\
\hline ВС036226 & 2.12 & AF244571 & 1.64 & AK091814 & 1.54 & CR617316 & 0.62 \\
\hline AF147427 & 2.08 & AK094655 & 1.63 & ВС041928 & 1.54 & AK057981 & 0.62 \\
\hline AK025152 & 2.01 & АК025388 & 1.63 & AF086037 & 1.54 & AF113697 & 0.62 \\
\hline АК026286 & 1.95 & АК074607 & 1.63 & ВC024172 & 1.54 & BC043240 & 0.62 \\
\hline AK128702 & 1.94 & AF075065 & 1.63 & АК021981 & 1.53 & AK055670 & 0.62 \\
\hline АК023887 & 1.89 & AK129971 & 1.63 & AF085866 & 1.53 & uc004ebm.1 & 0.62 \\
\hline AK055572 & 1.89 & АK023733 & 1.62 & AK094167 & 1.53 & AK098051 & 0.61 \\
\hline АК023302 & 1.88 & AF075111 & 1.62 & BC013931 & 1.53 & U09197 & 0.61 \\
\hline ВС035983 & 1.87 & AF289615 & 1.61 & AK024862 & 1.53 & BX648207 & 0.61 \\
\hline ВС007908 & 1.86 & AK022121 & 1.61 & AK022376 & 1.53 & AK128786 & 0.6 \\
\hline АВ062477 & 1.86 & АК025291 & 1.61 & AK022140 & 1.53 & AF119854 & 0.6 \\
\hline AK124099 & 1.86 & АК021821 & 1.6 & AK130460 & 1.52 & AL122062 & 0.59 \\
\hline AK123363 & 1.84 & ВC030757 & 1.59 & AK021554 & 1.52 & ВC041913 & 0.59 \\
\hline ВС035958 & 1.8 & AJ227898 & 1.59 & ВC026239 & 1.52 & BC027967 & 0.59 \\
\hline АК024517 & 1.8 & AK025552 & 1.59 & AF086356 & 1.52 & BX537762 & 0.59 \\
\hline AF086051 & 1.79 & ВС039388 & 1.59 & AF088069 & 1.52 & AK055612 & 0.58 \\
\hline АК022162 & 1.77 & АK022346 & 1.58 & АК095787 & 1.52 & AL049951 & 0.58 \\
\hline ВС025999 & 1.77 & AF075072 & 1.58 & ВС008462 & 1.52 & ВС036622 & 0.57 \\
\hline AF147324 & 1.75 & ВC035063 & 1.58 & AK127827 & 1.51 & CR601532 & 0.56 \\
\hline ВC043356 & 1.74 & AY952882 & 1.58 & AF085972 & 1.51 & CR611332 & 0.56 \\
\hline АК000942 & 1.73 & ВС008631 & 1.58 & AK023865 & 1.51 & X52767 & 0.56 \\
\hline AF086551 & 1.73 & AK026036 & 1.57 & AK098511 & 1.51 & CR622106 & 0.55 \\
\hline ВС043380 & 1.73 & AK022364 & 1.57 & AK024690 & 1.51 & CR608275 & 0.55 \\
\hline U43604 & 1.72 & AK022379 & 1.57 & BC035168 & 1.51 & АК021632 & 0.55 \\
\hline АК094967 & 1.72 & ВC017507 & 1.57 & AK074886 & 1.5 & AL157495 & 0.54 \\
\hline AK025210 & 1.71 & AF085833 & 1.57 & AK021862 & 1.5 & AL833097 & 0.53 \\
\hline AK124590 & 1.7 & АК024909 & 1.57 & ВС017944 & 1.5 & АК026078 & 0.53 \\
\hline AB051446 & 1.7 & AK001604 & 1.57 & AB075482 & 0.66 & CR618720 & 0.53 \\
\hline АК025818 & 1.7 & AK055807 & 1.57 & BC009638 & 0.66 & AK090972 & 0.51 \\
\hline АК024956 & 1.7 & ВС035091 & 1.57 & АК097103 & 0.66 & CR749465 & 0.51 \\
\hline АК055497 & 1.69 & АК022429 & 1.56 & CR606559 & 0.66 & AF147723 & 0.45 \\
\hline АК091973 & 1.69 & АК025126 & 1.56 & АК001279 & 0.66 & АК023330 & 0.44 \\
\hline AL833080 & 1.68 & AL833423 & 1.56 & ВС035180 & 0.65 & AB209021 & 0.42 \\
\hline AK054865 & 1.68 & АК025161 & 1.56 & CR592483 & 0.65 & BC015064 & 0.41 \\
\hline АK022159 & 1.68 & AF143326 & 1.55 & AK098425 & 0.65 & CR617865 & 0.39 \\
\hline AF086008 & 1.67 & ВС009608 & 1.55 & AF093744 & 0.65 & AK124833 & 0.38 \\
\hline АК093778 & 1.67 & АK025143 & 1.55 & AF116692 & 0.64 & & \\
\hline
\end{tabular}

3, two lncRNAs (AF264622 and AB209021) had the most excellent diagnostic capabilities in both cohorts.

Establishment of a molecular panel of two IncRNAs predictive of AR

With the two mostsignificantlncRNAs:AF264622 and AB209021, theARRSwas calculated in both cohorts. In the PRTx cohort, ARRS was generated as follows: ARRS=1.369*expression value of AF264622 -0.856*expression value of AB209021-3.368, and then subjected to ROC curve analysis (Fig. 4). As shown in Fig. 4, the generated ARRS could distinguish AR from STA patients with an AUC of 0.829 (95\% CI:0.735-0.922; $P<0.001$ ). Per the ROC curve analysis, 
Fig. 1. Unsupervised hierarchical cluster analysis of the differentially expressed lncRNAs. A. 162 differentially expressed IncRNAs in peripheral blood of 75 pediatric renal transplant recipients. B. 163 differentially expressed lncRNAs in 75 adult renal transplant peripheral blood samples.

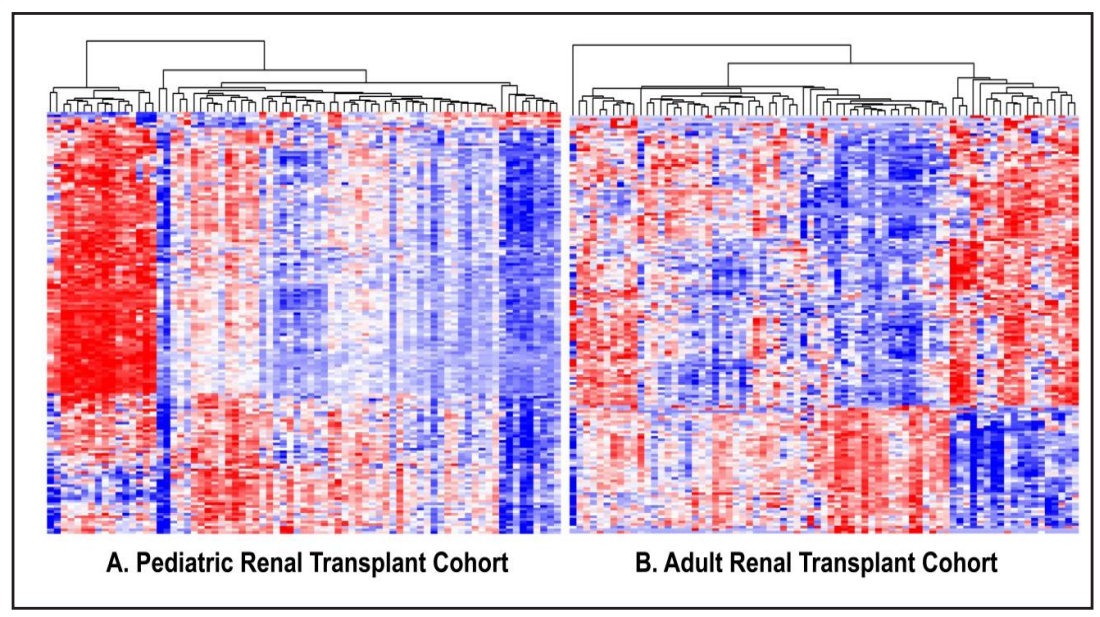

Fig. 2. Differentially expressed lncRNAs in pediatric and adult renal transplant recipients. Venn diagram of deregulated lncRNAs in both PRTx (pediatric renal transplant) and ARTx (adult renal transplant) cohorts.

an optimal cutoff value (1.886) with selected, and the diagnostic sensitivity and specificity of the two-lncRNA based ARRS for AR detection were 0.658 and 0.946 , respectively. In the ARRTx cohort, the same equation was applied to construct ARRS, which was further subjected to ROC curve analysis to determine its diagnostic performance (AUC: 0.889, 95\% CI: 0.817-0.960; $P<0.001$; Fig. 4). Finally, a cohort-specific cutoff value (1.228) was determined, with the corresponding sensitivity and specificity as 0.745 and 0.875 .

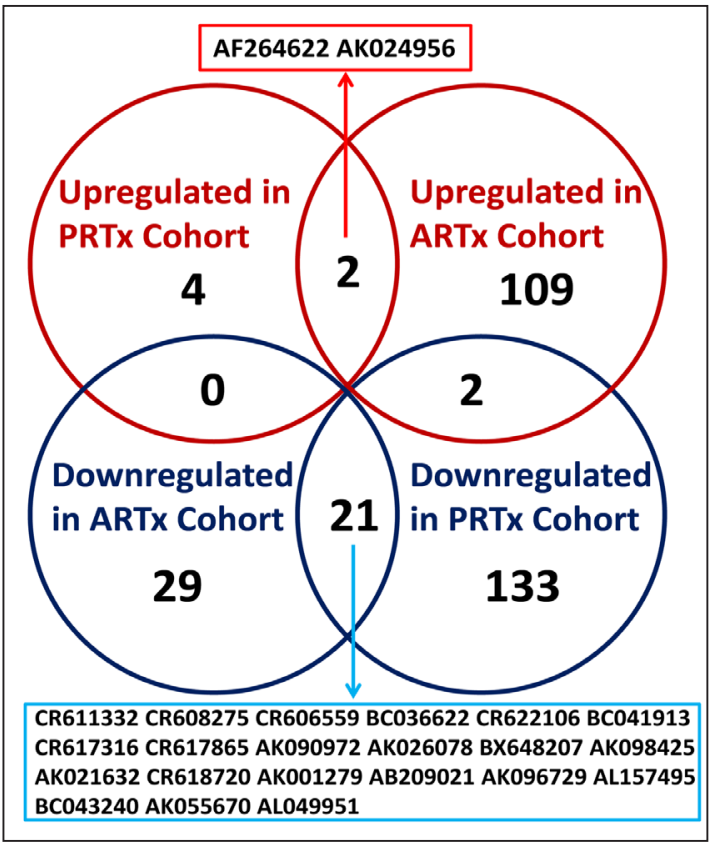

\section{Discussion}

Renal transplantation has processed from a risky experimental therapy to a safe and life-saving treatment for ESRD patients over the past five decades [2]. However, AR still remains a major determining factor which influences the short-term function and long-term outcome of both recipients and allografts [3]. Molecular classification of acute renal allograft rejection independent of invasive biopsy procedure is an unmet need in clinical practice [27$30]$. To the best of our knowledge, this is the first study to evaluate the lncRNA profiles in PB of renal transplant recipients. The major findings of the present study are as follows: 1 ) a variety of circulating lncRNAs were differentially expressed in AR recipients compared with those without AR, among which 23 deregulated accordingly in both PRTx and ARTx cohorts; 2) the 23 differentially expressed lncRNAs could discriminate AR recipients from those without stable renal allograft function in both cohorts, among which AF264622 and AB209021 exhibited the best diagnostic performance; 3) the two-lncRNA (AF264622 and AB209021) based ARRS could serve as a novel and non-invasive biomarker for the early diagnosis of AR in both pediatric and adult renal transplant recipients.

As an endogenous family of noncoding RNA, lncRNAs have been documented to regulate various pathophysiological processes including carcinogenesis and immune response [12, 


\begin{tabular}{|c|c|c|c|c|c|c|c|}
\hline \multirow{6}{*}{$\begin{array}{l}\text { Table 3. Summary of } \\
\text { twenty three lncRNAs } \\
\text { with diagnostic values } \\
\text { in both pediatric and } \\
\text { adult renal transplant } \\
\text { recipients }\end{array}$} & \multirow[t]{2}{*}{ IncRNA } & \multicolumn{3}{|c|}{ PRTx Cohort } & \multicolumn{3}{|c|}{ ARTx Cohort } \\
\hline & & AUC & $95 \% \mathrm{CI}$ & $P$ value & AUC & $95 \% \mathrm{CI}$ & $P$ value \\
\hline & \multicolumn{7}{|c|}{ Upregulated IncRNAs (AR vs. STA) } \\
\hline & AF264622 & 0.797 & $0.696-0.897$ & $<0.001$ & 0.862 & $0.782-0.942$ & $<0.001$ \\
\hline & AK024956 & 0.767 & $0.657-0.878$ & $<0.001$ & 0.759 & $0.648-0.870$ & $<0.001$ \\
\hline & \multicolumn{7}{|c|}{ Downregulated IncRNAs (AR vs. STA) } \\
\hline & AB209021 & 0.807 & $0.710-0.905$ & $<0.001$ & 0.846 & $0.758-0.933$ & $<0.001$ \\
\hline & AK026078 & 0.747 & $0.634-0.860$ & $<0.001$ & 0.813 & $0.715-0.911$ & $<0.001$ \\
\hline & ВС036622 & 0.753 & $0.643-0.864$ & $<0.001$ & 0.798 & $0.694-0.903$ & $<0.001$ \\
\hline & BX648207 & 0.779 & $0.671-0.886$ & $<0.001$ & 0.751 & $0.641-0.861$ & $<0.001$ \\
\hline & CR606559 & 0.743 & $0.630-0.855$ & $<0.001$ & 0.775 & $0.664-0.885$ & $<0.001$ \\
\hline & AK001279 & 0.768 & $0.659-0.878$ & $<0.001$ & 0.731 & $0.621-0.842$ & 0.001 \\
\hline & АK021632 & 0.684 & $0.559-0.808$ & 0.006 & 0.779 & $0.672-0.887$ & $<0.001$ \\
\hline & AK055670 & 0.853 & $0.768-0.938$ & $<0.001$ & 0.681 & $0.560-0.802$ & 0.012 \\
\hline & AK090972 & 0.718 & $0.599-0.838$ & 0.001 & 0.784 & $0.679-0.889$ & $<0.001$ \\
\hline & AK096729 & 0.767 & $0.659-0.876$ & $<0.001$ & 0.734 & $0.620-0.848$ & 0.001 \\
\hline & AK098425 & 0.738 & $0.620-0.855$ & $<0.001$ & 0.722 & $0.604-0.840$ & 0.002 \\
\hline & AL049951 & 0.742 & $0.629-0.855$ & $<0.001$ & 0.703 & $0.584-0.821$ & 0.005 \\
\hline & AL157495 & 0.708 & $0.589-0.827$ & 0.002 & 0.803 & $0.700-0.907$ & $<0.001$ \\
\hline & BC041913 & 0.669 & $0.542-0.795$ & 0.012 & 0.751 & $0.632-0.870$ & $<0.001$ \\
\hline & ВС043240 & 0.751 & $0.639-0.864$ & $<0.001$ & 0.715 & $0.599-0.831$ & 0.003 \\
\hline & CR608275 & 0.686 & $0.563-0.808$ & 0.006 & 0.832 & $0.734-0.929$ & $<0.001$ \\
\hline & CR611332 & 0.715 & $0.596-0.834$ & 0.001 & 0.761 & $0.655-0.868$ & $<0.001$ \\
\hline & CR617316 & 0.718 & $0.597-0.840$ & 0.001 & 0.806 & $0.707-0.905$ & $<0.001$ \\
\hline & CR617865 & 0.720 & $0.602-0.837$ & 0.001 & 0.833 & $0.735-0.931$ & $<0.001$ \\
\hline & CR618720 & 0.728 & $0.610-0.846$ & 0.001 & 0.807 & $0.708-0.907$ & $<0.001$ \\
\hline & CR622106 & 0.692 & $0.570-0.814$ & 0.004 & 0.878 & $0.802-0.954$ & $<0.001$ \\
\hline
\end{tabular}

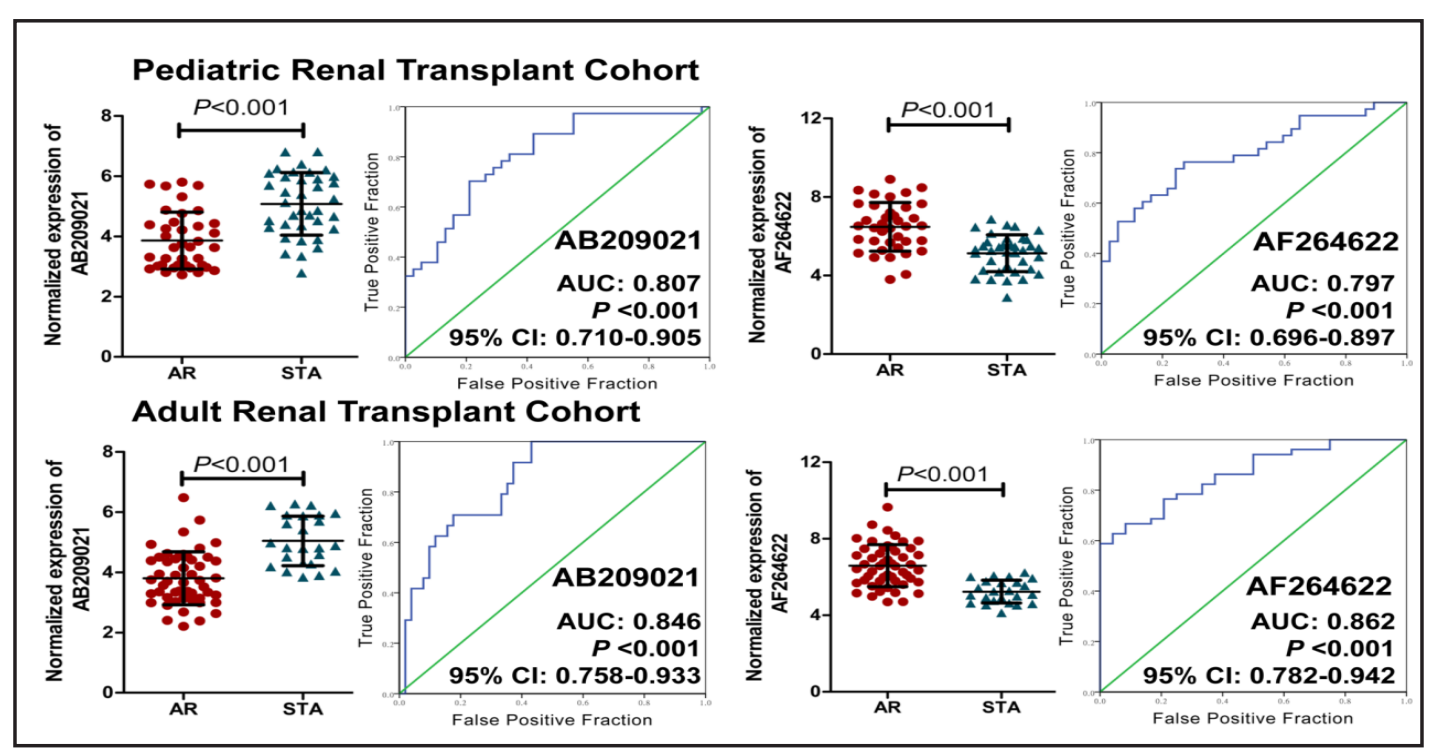

Fig. 3. Expression levels and diagnostic characteristics of circulating lncRNAs in pediatric and adult renal transplant recipients. The expression levels of each lncRNA between groups were compared with Student's t test. AR, acute rejection; STA, stable function; AUC, area under the curve; 95\% CI, 95\% confidential interval.

31]. Mounting evidence indicated lncRNAs in blood could serve as novel biomarkers for the early diagnosis and prognosis prediction of human diseases [32-34]. In renal transplantation, the global lncRNA expression levels have been profiled in three AR renal biopsy tissues and control tissues from three renal tumor patients, and a total of 5339 lncRNAs were proven 
Fig. 4. The molecular signature of two IncRNAs in peripheral blood for the diagnosis of acute rejection. A and D. IncRNA risk score distribution; $B$ and $E$. Heatmap of the IncRNA expression profiles; rows represent IncRNAs, and columns represent patients. The red dotted line represents the lncRNA signature cutoff value. C and F. Receiver operating characteristics curve analysis of the IncRNA signature for the diagnosis of acute rejection in renal transplant recipients.

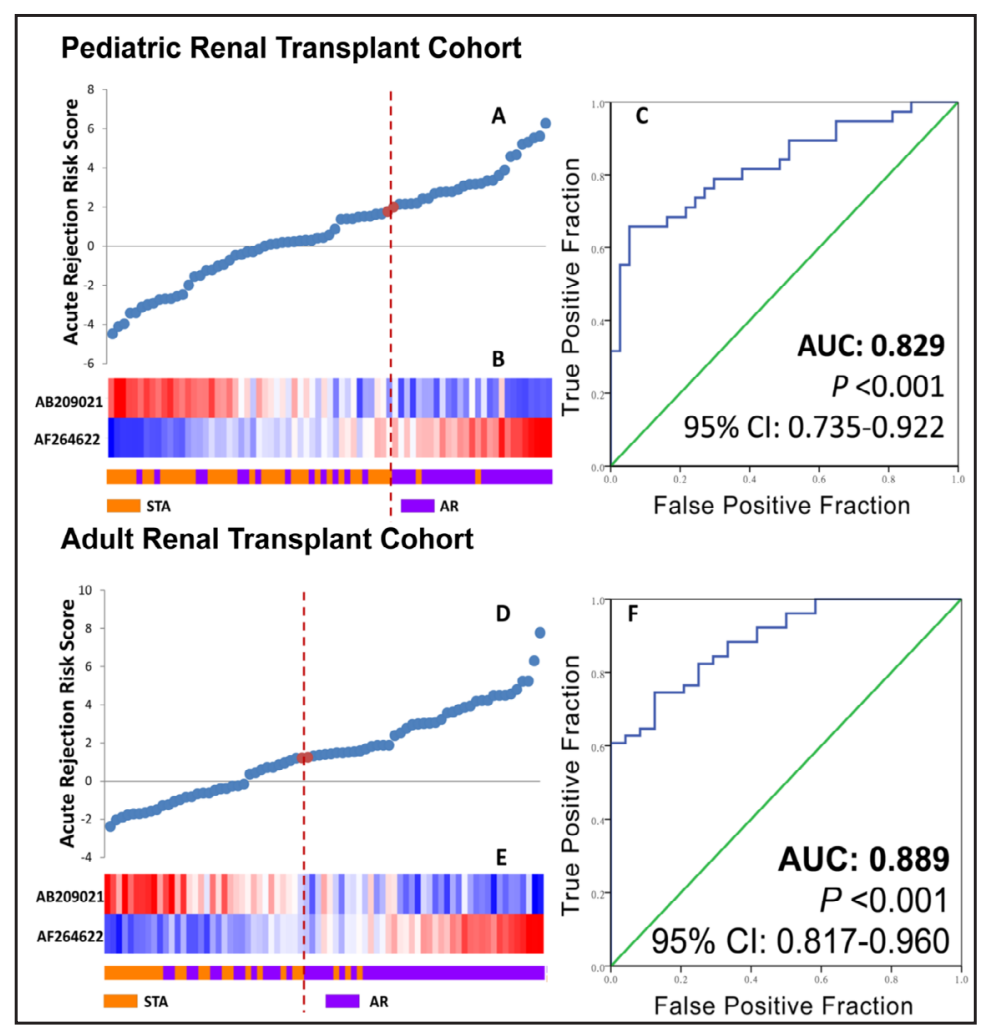

to differentially express between groups, among which five lncRNAs (AF113674, uc003wbj, uc010ftb, uc001fty, and AK129917) were selected for further validation and confirmed by quantificational real-time polymerase chain reaction (qRT-PCR) $[16,17]$. In a recent clinical study, Lorenzen et al. comprehensively analyzed the genome-wide lncRNA expression profiles in the urine samples (9 ATMR vs. 9 STA recipients), and found a summary of 4189 differentially expressed lncRNAs. During the further validation in a cohort of 93 recipients (62 ATMR vs. 31 STA) with qRT-PCR, urinary RP11-354P17.15-001 was proven as a reliable biomarker for the diagnosis of ATMR [19]. However, to date, the lncRNA expression profiles in PB of renal transplant recipients have never been studied.

In this two-cohort observational study with 150 renal transplant recipients, we comprehensively analyzed the genome-wide lncRNA expression profiles in PB samples via mining Affymetrix HG-U133 Plus 2.0 microarray data. Among the 5635 re-annotated lncRNA transcripts, 162 were aberrantly expressed in PRTx cohort and 163 in ARTx cohort. Of all these differentially expressed IncRNAs, a total of 23 dysregulated accordingly in both cohorts, and could discriminate AR recipients from those without AR. Finally, with the two lncRNAs (AF264622 and AB209021), an ARRS was generated and proven to distinguish AR patients with excellent diagnostic performance (PRTx cohort: AUC:0.829, 95\% CI:0.735-0.922; and ARTx cohort: AUC: 0.889, 95\% CI: 0.817-0.960).

Of these two AR-related lncRNAs: AF264622 and AB209021, none has been studied previously. AF264622 is a 484 bp IncRNA located with the intron of solute carrier family 8 , member 1 (SLC8A1), which is located on chromosome 2p22.1. The SLC family consists of over 300 membrane-bound proteins that facilitate transporting of various substrates across biological membranes, which in turn exert fundamental functions in pathophysiological processes including acute renal allograft rejection [35,36]. However, as one member of SLC family, the biological roles of SLC8A1 in renal transplant remain yet to investigate. AB209021 is located on chromosome 3q27.3, which spans $5267 \mathrm{bp}$ and consists of three exons. Structurally, AB209021 shares the exon sense-overlapping relationship with the gene eukaryotic translation initiation factor $4 \mathrm{~A} 2$, which is a highly conserved gene for one 


\section{Cellular Physiology Cell Physiol Biochem 2017;44:1213-1223 \begin{tabular}{ll|l} 
DOI: 10.1159/000485451 & $\begin{array}{l}\text { O 2017 The Author(s). Published by S. Karger AG, Basel } \\
\text { www.karger.com/cpb }\end{array}$ \\
\hline
\end{tabular}

of the protein-synthesis initiation factors involved in the binding of mRNA to the ribosome [37]. Overall, these two lncRNAs might play substantial roles in the fundamental biological processes, which warrant further comprehensive biological investigations.

Some limitations should be acknowledged in interpreting the results. First, a total of 5635 eligible IncRNAs were initially identified via mining Affymetrix HG-U133 Plus 2.0 microarray data and included in the current study, which accounted for about $35.7 \%$ (5635/15767, data form GENCODE) and the number of total identified lncRNAs in human beings is still growing [38]. Hence, the diagnostic lncRNAs identified here may not represent all the IncRNA candidates of diagnostic values for the prediction of AR. Second, the lack of traditional diagnostic parameters such serum creatinine and blood urine nitrogen, which hindered the comparison of the diagnostic performance between the newly generated ARRS and traditional biomarkers. Third, even though two independent well-matched cohorts were included and robust statistical analyses were applied, the false-positive results do potentially exist, which need an external validation cohort to validate the results with different methods such as qRT-PCR.

\section{Conclusion}

In summary, by analyzing the genome-wide lncRNA expression profiles in the PB samples of renal transplant recipients from two independent well-matched cohorts, our study identified the specific circulating lncRNAs differentially expressed between AR and STA patients, and a molecular signature of two lncRNAs (AF264622 and AB209021) in PB, which could serve as a novel non-invasive biomarker for the early diagnosis of AR in both pediatric and adult renal transplant recipients. Further validation studies are warranted to verify our findings within prospectively designed clinical trials and comprehensive biological experiments.

\section{Acknowledgements}

This study was supported by grants from the National Natural Science Foundation of China (81370853 and 81570613) to Prof. Rui-Peng Jia, and Research and Innovation Program for Graduates of Jiangsu Province (CXZZ13_0583), Jiangsu Provincial Medical Youth Talent (QNRC2016073), Key Program of Science and Technology Foundation from Nanjing Medical University (2016NJMUZD042), and the Natural Science Foundation of Jiangsu Province (BK20170135) to Dr. Yu-Zheng Ge.

\section{Disclosure Statement}

The authors declare that they have no competing interests.

\section{References}

-1 Reese PP, Shults J, Bloom RD, Mussell A, Harhay MN, Abt P, Levine M, Johansen KL, Karlawish JT, Feldman HI: Functional Status, Time to Transplantation, and Survival Benefit of Kidney Transplantation Among Wait-Listed Candidates. Am J Kidney Dis 2015;66:837-845.

2 Glassock RJ, Warnock DG, Delanaye P: The global burden of chronic kidney disease: estimates, variability and pitfalls. Nat Rev Nephrol 2017;13:104-114.

3 Wu WK, Famure O, Li Y, Kim SJ: Delayed graft function and the risk of acute rejection in the modern era of kidney transplantation. Kidney Int 2015;88:851-858. 


\section{Cellular Physiology Cell Physiol Biochem 2017;44:1213-1223 \begin{tabular}{l|l|l}
\hline and Biochemistry 10.1159/000485451 & $\begin{array}{l}\text { C } 2017 \text { The Author(s). Published by S. Karger AG, Basel } \\
\text { www.karger.com/cpb }\end{array}$ \\
\hline
\end{tabular}}

4 Becker LE, Morath C, Suesal C: Immune mechanisms of acute and chronic rejection. Clin Biochem 2016;49:320-323.

-5 Schwarz A, Gwinner W, Hiss M, Radermacher J, Mengel M, Haller H: Safety and adequacy of renal transplant protocol biopsies. Am J Transplant 2005;5:1992-1996.

6 Li L, Khatri P, Sigdel TK, Tran T, Ying L, Vitalone MJ, Chen A, Hsieh S, Dai H, Zhang M, Naesens M, Zarkhin V, Sansanwal P, Chen R, Mindrinos M, Xiao W, Benfield M, Ettenger RB, Dharnidharka V, Mathias R, Portale A, McDonald R, Harmon W, Kershaw D, Vehaskari VM, Kamil E, Baluarte HJ, Warady B, Davis R, Butte AJ, Salvatierra 0, Sarwal MM: A peripheral blood diagnostic test for acute rejection in renal transplantation. Am J Transplant 2012;12:2710-2718.

-7 Kurian SM, Williams AN, Gelbart T, Campbell D, Mondala TS, Head SR, Horvath S, Gaber L, Thompson R, Whisenant T, Lin W, Langfelder P, Robison EH, Schaffer RL, Fisher JS, Friedewald J, Flechner SM, Chan LK, Wiseman AC, Shidban H, Mendez R, Heilman R, Abecassis MM, Marsh CL, Salomon DR: Molecular classifiers for acute kidney transplant rejection in peripheral blood by whole genome gene expression profiling. Am J Transplant 2014;14:1164-1172.

8 Suthanthiran M, Schwartz JE, Ding R, Abecassis M, Dadhania D, Samstein B, Knechtle SJ, Friedewald J, Becker YT, Sharma VK, Williams NM, Chang CS, Hoang C, Muthukumar T, August P, Keslar KS, Fairchild RL, Hricik DE, Heeger PS, Han L, Liu J, Riggs M, Ikle DN, Bridges ND, Shaked A, Clinical Trials in Organ Transplantation 04 Study I: Urinary-cell mRNA profile and acute cellular rejection in kidney allografts. N Engl J Med 2013;369:20-31.

-9 Lee JR, Muthukumar T, Dadhania D, Ding R, Sharma VK, Schwartz JE, Suthanthiran M: Urinary cell mRNA profiles predictive of human kidney allograft status. Immunol Rev 2014;258:218-240.

10 St Laurent G, Wahlestedt C, Kapranov P: The Landscape of long noncoding RNA classification. Trends Genet 2015;31:239-251.

-11 Quinn JJ, Chang HY: Unique features of long non-coding RNA biogenesis and function. Nat Rev Genet 2016;17:47-62.

12 Heward JA, Lindsay MA: Long non-coding RNAs in the regulation of the immune response. Trends Immunol 2014;35:408-419.

13 Sullenger BA, Nair S: From the RNA world to the clinic. Science 2016;352:1417-1420.

14 Wang L, Chen Z, An L, Wang Y, Zhang Z, Guo Y, Liu C: Analysis of Long Non-Coding RNA Expression Profiles in Non-Small Cell Lung Cancer. Cell Physiol Biochem 2016;38:2389-2400.

15 Qi M, Zhou Q, Zeng W, Shen M, Liu X, Luo C, Long J, Chen W, Zhang J, Yan S: Analysis of Long Non-Coding RNA Expression of Lymphatic Endothelial Cells in Response to Type 2 Diabetes. Cell Physiol Biochem 2017;41:466-474.

16 Sui W, Lin H, Peng W, Huang Y, Chen J, Zhang Y, Dai Y: Molecular dysfunctions in acute rejection after renal transplantation revealed by integrated analysis of transcription factor, microRNA and long noncoding RNA. Genomics 2013;102:310-322.

17 Chen W, Peng W, Huang J, Yu X, Tan K, Chen Y, Lin X, Chen D, Dai Y: Microarray analysis of long non-coding RNA expression in human acute rejection biopsy samples following renal transplantation. Mol Med Rep 2014;10:2210-2216.

-18 Qiu J, Chen Y, Huang G, Zhang Z, Chen L, Na N: The TGF-beta activated long non-coding RNA ATB plays an important role in acute rejection of renal allografts and may impacts the postoperative pharmaceutical immunosuppression therapy. Nephrology (Carlton) 2016;10.1111/nep.12851

-19 Lorenzen JM, Schauerte C, Kolling M, Hubner A, Knapp M, Haller H, Thum T: Long Noncoding RNAs in Urine Are Detectable and May Enable Early Detection of Acute T Cell-Mediated Rejection of Renal Allografts. Clin Chem 2015;61:1505-1514.

20 von Elm E, Altman DG, Egger M, Pocock SJ, Gotzsche PC, Vandenbroucke JP, Initiative S: The Strengthening the Reporting of Observational Studies in Epidemiology (STROBE) statement: guidelines for reporting observational studies. Lancet 2007;370:1453-1457.

21 Solez K, Colvin RB, Racusen LC, Haas M, Sis B, Mengel M, Halloran PF, Baldwin W, Banfi G, Collins AB, Cosio F, David DS, Drachenberg C, Einecke G, Fogo AB, Gibson IW, Glotz D, Iskandar SS, Kraus E, Lerut E, Mannon RB, Mihatsch M, Nankivell BJ, Nickeleit V, Papadimitriou JC, Randhawa P, Regele H, Renaudin K, Roberts I, Seron D, Smith RN, Valente M: Banff 07 classification of renal allograft pathology: updates and future directions. Am J Transplant 2008;8:753-760. 


\section{Cellular Physiology Cell Physiol Biochem 2017;44:1213-1223 \begin{tabular}{l|l|l} 
DOI: 10.1159/000485451 & $\begin{array}{l}\text { O 2017 The Author(s). Published by S. Karger AG, Basel } \\
\text { www.karger.com/cpb }\end{array}$
\end{tabular}}

22 Risueno A, Fontanillo C, Dinger ME, De Las Rivas J: GATExplorer: genomic and transcriptomic explorer; mapping expression probes to gene loci, transcripts, exons and ncRNAs. BMC Bioinformatics 2010;11:221.

23 Pang KC, Stephen S, Dinger ME, Engstrom PG, Lenhard B, Mattick JS: RNAdb 2.0--an expanded database of mammalian non-coding RNAs. Nucleic Acids Res 2007;35:D178-182.

24 Zhao Y, Li H, Fang S, Kang Y, Wu W, Hao Y, Li Z, Bu D, Sun N, Zhang MQ, Chen R: NONCODE 2016: an informative and valuable data source of long non-coding RNAs. Nucleic Acids Res 2015;10.1093/nar/ gkv1252

25 Zhao Y, Simon R: BRB-ArrayTools Data Archive for human cancer gene expression: a unique and efficient data sharing resource. Cancer Inform 2008;6:9-15.

-26 Lin XJ, Chong Y, Guo ZW, Xie C, Yang XJ, Zhang Q, Li SP, Xiong Y, Yuan Y, Min J, Jia WH, Jie Y, Chen MS, Chen MX, Fang JH, Zeng C, Zhang Y, Guo RP, Wu Y, Lin G, Zheng L, Zhuang SM: A serum microRNA classifier for early detection of hepatocellular carcinoma: a multicentre, retrospective, longitudinal biomarker identification study with a nested case-control study. Lancet Oncol 2015;16:804-815.

27 Ge YZ, Wu R, Jia RP, Liu H, Yu P, Zhao Y, Feng YM: Association between interferon gamma +874 T>A polymorphism and acute renal allograft rejection: evidence from published studies. Mol Biol Rep 2013;40:6043-6051.

28 Ge YZ, Yu P, Jia RP, Wu R, Ding AX, Li LP, Zhao Y, Feng YM, Gui ZL, Liao S: Association between transforming growth factor beta-1+869T/C polymorphism and acute rejection of solid organ allograft: A meta-analysis and systematic review. Transpl Immunol 2014;30:76-83.

29 Ge YZ, Wu R, Lu TZ, Jia RP, Li MH, Gao XF, Jiang XM, Zhu XB, Li LP, Tan SJ, Song Q Li WC, Zhu JG: Combined effects of TGFB1 $+869 \mathrm{~T} / \mathrm{C}$ and $+915 \mathrm{G} / \mathrm{C}$ polymorphisms on acute rejection risk in solid organ transplant recipients: a systematic review and meta-analysis. PLoS One 2014;9:e93938.

-30 Menon MC, Keung KL, Murphy B, O’Connell PJ: The Use of Genomics and Pathway Analysis in Our Understanding and Prediction of Clinical Renal Transplant Injury. Transplantation 2015;10.1097/ TP.0000000000000943

31 Qiu M, Feng D, Zhang H, Xia W, Xu Y, Wang J, Dong G, Zhang Y, Yin R, Xu L: Comprehensive analysis of lncRNA expression profiles and identification of functional lncRNAs in lung adenocarcinoma. Oncotarget 2016;7:16012-16022.

-32 Hu HB, Jie HY, Zheng XX: Three Circulating LncRNA Predict Early Progress of Esophageal Squamous Cell Carcinoma. Cell Physiol Biochem 2016;40:117-125.

33 Qiu ZL, Shen CT, Sun ZK, Wei WJ, Zhang XY, Song HJ, Luo QY: Circulating Long Non-Coding RNAs Act as Biomarkers for Predicting 131I Uptake and Mortality in Papillary Thyroid Cancer Patients with Lung Metastases. Cell Physiol Biochem 2016;40:1377-1390.

34 Gu M, Zheng A, Tu W, Zhao J, Li L, Li M, Han S, Hu X, Zhu J, Pan Y, Xu J, Yu Z: Circulating LncRNAs as Novel, Non-Invasive Biomarkers for Prenatal Detection of Fetal Congenital Heart Defects. Cell Physiol Biochem 2016;38:1459-1471.

-35 Einecke G, Broderick G, Sis B, Halloran PF: Early loss of renal transcripts in kidney allografts: relationship to the development of histologic lesions and alloimmune effector mechanisms. Am J Transplant 2007;7:1121-1130.

-36 Einecke G, Kayser D, Vanslambrouck JM, Sis B, Reeve J, Mengel M, Famulski KS, Bailey CG, Rasko JE, Halloran PF: Loss of solute carriers in T cell-mediated rejection in mouse and human kidneys: an active epithelial injury-repair response. Am J Transplant 2010;10:2241-2251.

-37 Lu WT, Wilczynska A, Smith E, Bushell M: The diverse roles of the eIF4A family: you are the company you keep. Biochem Soc Trans 2014;42:166-172.

-38 Harrow J, Frankish A, Gonzalez JM, Tapanari E, Diekhans M, Kokocinski F, Aken BL, Barrell D, Zadissa A, Searle S, Barnes I, Bignell A, Boychenko V, Hunt T, Kay M, Mukherjee G, Rajan J, Despacio-Reyes G, Saunders G, Steward C, Harte R, Lin M, Howald C, Tanzer A, Derrien T, Chrast J, Walters N, Balasubramanian S, Pei B, Tress M, Rodriguez JM, Ezkurdia I, van Baren J, Brent M, Haussler D, Kellis M, Valencia A, Reymond A, Gerstein M, Guigo R, Hubbard TJ: GENCODE: the reference human genome annotation for The ENCODE Project. Genome Res 2012;22:1760-1774. 